\title{
The Administration of Cobalt by Different Routes to Lambs Maintained on a Low-Cobalt Diet
}

\author{
By A. T. PHILLIPSON \\ Rowett Research Institute, Bucksburn, Aberdeenshire \\ AND R. L. MITCHELL \\ Macaulay Institute for Soil Research, Aberdeen
}

(Received I6 Yuly 1951)

The importance of cobalt in the nutrition of the sheep was discovered in Australasia (Lines, 1935; Marston, 1935; Underwood \& Filmer, 1935; Askew \& Dixon, 1936), and it was assumed that its action was exerted in the rumen, as neither horses nor rabbits maintained on cobalt-deficient land show signs of deficiency. Injection of cobalt salts or vitamin $B_{12}$ does not prevent or cure deficiency (Marston \& Lee, 1949), although some improvement may be noticed after the injection of large doses of cobalt (Ray, Weir, Pope, Bohstedt \& Phillips, I948; Keener, Percival, Ellis \& Beeson, 1950).

There was no direct evidence to show how the rumen might be concerned until Tosic \& Mitchell (1948) found that bacteria in the rumen concentrated cobalt from the surrounding media. One hypothesis suggested by this observation was that the rumen bacteria require cobalt for their normal metabolism. Concentration of trace elements by bacteria, however, may be fortuitous and the possibility also exists that, when the available cobalt is short, its concentration in bacterial cells may mean that none is available for essential purposes elsewhere. Masson (1950) has shown that some rumen micro-organisms disintegrate as they pass through the abomasum, and others as they pass along the small intestine; for this reason it is improbable that free cobalt is necessary in the lower parts of the alimentary tract. Injection of radioactive cobalt demonstrated the excretion of a part of it in the bile (Comar \& Davis, 1947); in addition, traces of activity were found in both small and large intestines and even in the abomasum. This suggests that the action of cobalt may be confined to the rumen, but, as the counts recorded by Comar $\&$ Davis from the abomasum and intestines were very small, additional investigations were needed.

The experiments described here were designed to establish whether the action of cobalt could be localized to the rumen.

\section{EXPERIMENTAL}

General. Four experiments were carried out. The first was designed to test the adequacy of the ration with added or injected cobalt. The second was designed to ascertain whether nicotinic-acid deficiency was being caused by the excessive quantity of maize in the ration. The third and fourth were designed to study the effect of introducing cobalt into the alimentary tract caudally to the rumen and reticulum. 
A modification of the ration used by Stewart (1947) was used to produce and maintain cobalt-deficient animals.

All lambs were kept individually in wooden pens treated with creosote; metal fittings were removed and the floors were slatted so that faeces dropped through. This is an important precaution, as Comar, Davis, Taylor, Huffman \& Ely (1946) have shown that $65 \%$ of radioactive cobalt introduced into the rumen is excreted in the faeces. Drinking water was placed in china bowls, and wooden feeding troughs were fitted with an overhanging wooden ridge to prevent the scatter of food. Kitchen cooking salt was always available in china bowls.

All nails or screwheads on the pens were painted over with a plastic paint to prevent the sheep licking them.

\section{Source of animals}

Experiment I. The lambs used in the first experiment were obtained from a farm in the north of Morayshire; part of this land had been used as an aerodrome during the war and levelling operations had brought the subsoil to the surface.* Samples of soil taken from the part of the farm in question contained from 0.10 to 0.16 p.p.m. of cobalt soluble in $2.5 \%$ acetic acid. In Scotland, 0.3 p.p.m. probably indicates an adequate cobalt concentration in normal soils.

Twenty-four Cheviot lambs, 60-80 days old, were placed on these pastures; twelve were maintained on untreated pasture and twelve others, to which were added a few late lambs, were maintained on an adjacent pasture that had been treated with cobalt sulphate at the rate of $2 \mathrm{lb}$./acre. When the two groups were weighed, approximately 2 months later, a marked difference had developed between them, as shown in Table 1 .

Table I. Exp. I. Weights of Cheviot lambs that had been kept for 2 months on treated and untreated cobalt-deficient pasture

$\begin{array}{ccc}\begin{array}{c}\text { Main group } \\ \text { (lb.) }\end{array} & \begin{array}{c}\text { Late lambs } \\ \text { (lb.) }\end{array} & \begin{array}{c}\text { Untreated } \\ \text { pasture } \\ (\text { lb. })\end{array} \\ 84 & 48 \text { (6 weeks old) } & 37 \frac{1}{2} \\ 68 \frac{1}{2} & 31 \text { (3 weeks old) } & 83 \\ 83 \frac{1}{2} & 31 \frac{1}{2}(3 \text { weeks old }) & 32 \\ 77 \frac{1}{2} & 35 \text { (3 weeks old) } & 66 \frac{1}{2} \\ 66 & - & 30 \\ 66 & - & 58 \\ 77 & - & 45 \frac{1}{2} \\ 76 \frac{1}{2} & - & 55 \\ 63 \frac{1}{2} & - & 41 \frac{1}{2} \\ 72 \frac{1}{2} & - & 33 \\ 66 & - & 33 \frac{1}{2} \\ 53 & - & 62 \\ \text { Mean } 71 & - & 48\end{array}$

Seven of the twelve animals on the untreated pasture were badly underweight and comparable to the younger lambs on the treated pasture. A complication was that all

* We are indebted to Dr A. B. Stewart for suggesting the source of the first batch of cobalt-deficient lambs. 
lambs in both groups harboured the tape worm, Monieza expansa, but faecal examination suggested that the infestation was no greater in the deficient group than in the treated group. It is well known that comparatively heavy infestations of sheep with this parasite do not appear to be harmful. The six lightest animals from the untreated pasture were taken for experiment. Three weeks later the remaining lambs on the untreated pasture were weighed again and two that had made no weight increases were added to the experiment.

Experiment 2. The lambs used in the second experiment had been bred from Cheviot ewes in this Institute. The ewes were maintained during the later stages of pregnancy on hay and oats grown on cobalt-deficient land. The lambs were placed on the experimental diet after weaning.

Experiments 3 and 4 . The lambs used in the third and fourth experiments were reared on a known cobalt-deficient area in the Solway region; those used in the third experiment were Blackfaces and those in the fourth experiment Border LeicesterBlackface crossbreds. The condition of the lambs in both the third and fourth groups when they arrived at the laboratory was fairly good and suggested no severe deficiency of the pasture upon which they had been reared.

\section{The ration}

Analysis of the hay used in these experiments showed that it had a cobalt content of 0.19 P.p.m. This was too high to produce deficiency, but samples analysed after it had been chopped and shaken, to remove dust and weed seeds, had a much lower content: $0.06-0.09$ p.p.m. Even so it was necessary to restrict severely the quantity allowed, in order to be sure of attaining deficiency in the ration. The cobalt concentration in all constituents of the ration is given in Table 2.

Table 2. The cobalt content of the constituents of the ration

$\begin{array}{lc}\text { Constituent } & \text { Cobalt } \\ \text { Chopped hay } & \text { (p.p.m. in dry matter) } \\ \text { Flaked maize } & 0.06-0.09 \\ \text { Maize-gluten feed } & 0.03 \\ \text { Steamed bone-flour } & 0.04-0.07 \\ \text { Salt } & 0.27 \\ \text { Cod-liver oil } & \text { None detected } \\ & \text { None detected }\end{array}$

It is believed that the concentration of cobalt in pasture grass below which deficiency will occur is 0.07 p.p.m. It was necessary, therefore, to mix the available foodstuffs in such proportions that the concentration was well below this figure. Hay was fed separately at 4 p.m. The flaked maize mixture was fed at 8 a.m. Food residues were weighed, so that the quantity of hay and maize mixture consumed was known.

The lambs in Exps. I-3 received $200 \mathrm{~g}$, and those in Exp. 4 received $150 \mathrm{~g}$ hay daily. Flaked maize and maize-gluten feed were mixed in the proportions of $10: 1$, and the animals were allowed as much of this mixture as they would eat up to a maximum of I $\mathrm{kg}$ daily. In practice the mixture was offered at the rate of $100 \mathrm{~g}$ above the previous day's food consumption until it was all eaten in a day. It was then increased by another 
roo $\mathrm{g}$. Twelve $\mathrm{g}$ of steamed bone-flour were added to the maize ration daily. The quantity of cobalt ingested, therefore, varied with the quantity of maize mixture eaten, but even at the maximum allowance of $\mathrm{I}$ kg daily the cobalt obtained from the ration was well below that from a hay diet containing 0.07 p.p.m., i.e. approximately $70 \mu \mathrm{g}$. The relevant figures are given in Table 3 .

\section{Table 3. Daily intake of cobalt by the lambs in the four experiments}

(The highest content of cobalt for each foodstuff given in Table 2 was used to compute total cobalt)

\begin{tabular}{|c|c|c|}
\hline \multirow{2}{*}{ Foodstuff } & \multicolumn{2}{|c|}{ Cobalt } \\
\hline & $\begin{array}{c}\text { p.p.m. } \\
0.09\end{array}$ & $\begin{array}{l}\text { Total } \\
(\mu \mathrm{g}) \\
\mathrm{I} 8\end{array}$ \\
\hline Hay, $15 \circ \mathrm{g}$ & 0.09 & 13 \\
\hline Flaked maize, $900 \mathrm{~g}$ & 0.03 & 27 \\
\hline Maize-gluten feed, $95 \mathrm{~g}$ & 0.07 & 7 \\
\hline Steamed bone-flour, $12 \mathrm{~g}$ & 0.27 & 3 \\
\hline \multirow{2}{*}{\multicolumn{2}{|c|}{$\begin{array}{l}\text { Ration ( } \mathrm{I}): 200 \mathrm{~g} \text { hay }+995 \mathrm{~g} \text { maize mixture and } \\
\mathrm{I2} \mathrm{g} \text { steamed bone-flour } \\
\text { Ration (2): } 150 \mathrm{~g} \text { hay }+995 \mathrm{~g} \text { maize mixture and } \\
\mathrm{I2} \mathrm{g} \text { steamed bone-flour }\end{array}$}} & 55 \\
\hline & & 50 \\
\hline
\end{tabular}

Though this ration is an unusual one, once the lambs were accustomed to it they gained reasonably satisfactorily in weight when additional cobalt was given by mouth.

\section{Surgical procedures}

Each animal in Exp. 3 was fitted with a small perspex cannula in the lower part of the duodenum, caudal to the common entrance of the bile and pancreatic ducts. Eight of the twelve animals in Exp. 4 were fitted with a rumen cannula and all animals were fitted with either a duodenal or an abomasal cannula.

The anaesthetic used was pentobarbitone (Nembutal) by intravenous injection and the usual aseptic precautions were adopted.

Rumen operations were performed in the usual way. Small-bore ebonite cannulas were used, having an internal diameter of ro $\mathrm{mm}$ and an internal collar of $50 \mathrm{~mm}$. The usual anatomical approach was made and the cannula was exteriorized through a stab wound approximately $I-1 \frac{1}{2}$ in. oral to the incision. Abomasal cannulas were of the following dimensions: internal diam. ro $\mathrm{mm}$, internal collar $30 \mathrm{~mm}$. An incision 8-10 in. long was made on the right of the epigastric region parallel to the line of the last rib and separated from it by $2-3$ in. The abomasum was located by the great omentum; if the organ was not lying within sight, gentle traction on the omentum brought it to the incision. The cannula was inserted into the lateral surface of the pyloric portion of the abomasum in the usual way and was exteriorized between the incision and the last rib.

In order to insert a cannula into the lower part of the duodenum an incision was made high up in the right side, beginning about $\mathrm{I}$ in. below the transverse processes of the lumbar vertebras and extending towards the mid-line of the abdomen for 
8-10 in. The duodenum was found to lie transversely to the incision and was dissected free of the mesocolon for a distance of 3 in., so that no subsequent tension could draw it away from the abdominal wall. The cannula was inserted and the usual 'purse string'-suture closure of the intestinal incision was used. The shaft was then exteriorized either in front or behind the incision in the abdominal wall, depending on its position when the duodenum was returned to the abdomen.

It is unnecessary to suture either the rumen, abomasum or duodenum to the abdominal wall provided the cannula is exteriorized where no tension can be exerted on it. With the rumen and abomasum there is little danger of this happening, but the duodenum must be allowed to lie in its natural position. In all operations the simplest surgical manipulations possible were used; the fact that all animals recovered uneventfully amply justified the methods.

Sulphathiazole containing $0.2 \%$ sodium penicillinate was insufflated around the internal orifice of the stab wound and over the peritoneal surface of adjacent viscera before closing the incision.

The animals in these experiments were transferred to their pens as soon as the operation was over, so that there was no possibility of their obtaining cobalt-rich foodstuffs. All lambs were weighed twice weekly throughout the experimental period.

\section{Administration of cobalt}

Solutions of cobalt sulphate containing either $\mathrm{I}$ or $\mathrm{O} \cdot \mathrm{I} \mathrm{mg}$ cobalt in $\mathrm{I} \mathrm{ml}$. were administered from a $2 \mathrm{ml}$. syringe into the mouth or duodenum. Cobalt by injection was given intravenously into the jugular vein as a sterile solution of the same concentration. All doses, except in Exp. 4, were given daily.

In Exp. 4 it was found impracticable to administer cobalt by syringe into the abomasum. On account of this, $4 \mathrm{mg}$ cobalt in the form of cobalt sulphate were laid on a piece of lint which was rolled into a cylinder fitting the cannula. The shafts of the abomasal and duodenal cannulas of this group of lambs were plugged with this rolled lint impregnated with cobalt, so that the inner part of the plug projected into the lumen of the organ. The plugs were changed every 4 days. In this way cobalt slowly diffused from the gauze into the organ. Control animals in this group received either no additional cobalt or $0.1 \mathrm{mg}$ cobalt by mouth daily.

\section{Analytical procedures}

Livers were weighed, cut into small pieces with stainless steel scissors, placed in tared silica basins and weighed. They were dried in a stainless steel oven at $110^{\circ}$ to constant weight. Ashing was begun over an open bunsen flame. Asbestos squares, with holes cut to fit the basins exactly, were used. Gentle heating was applied until the 'frothing stage' was over. The basins were then placed in a thermostatically controlled muffle and ashed at $500^{\circ}$ to constant weight.

The cobalt content of the ash was determined spectrographically after chemical concentration (Mitchell, 1948; Mitchell \& Scott, 1948).

Rumen contents of animals in Exp. 4 were withdrawn by suction from the rumen of each sheep with a rumen cannula in the $15^{\text {th }}$ week of the experiment, as it was 
important to discover whether the cobalt concentration in the rumen was affected by the method of dosing. Rumen liquor (100 ml.) was withdrawn, dried to constant weight and ashed at $500^{\circ}$.

\section{Experiment I}

RESULTS

The animals of this experiment were used to ascertain whether cobalt deficiency could be maintained by feeding the experimental ration and whether the ration was adequate if cobalt was given orally, and to re-investigate the claim that cobalt given by injection was ineffective in preventing deficiency.

The best and the worst of the first six lambs were placed in the group receiving cobalt by mouth; the weights of the other animals were so similar that there was little to choose between them. These animals already showed a severe degree of pining and, coming from grass, they did not take well to the experimental ration. Their appetites were very poor, except for one animal receiving cobalt by mouth. Two further animals taken later from the cobalt-deficient pasture were placed in the experiment after two deaths had occurred. The weight changes are given in Table 4 .

Table 4. Exp. 1. Weight changes (lb.) from initial weight of lambs after stated periods on the deficient ration

$\begin{array}{ll}\text { nb } & \text { Initial } \\ \text { J. } & \text { wt. } \\ \text { '2 } & 37 \frac{1}{2} \\ \text { '4 } & 30 \\ 15 & 43 \\ \text { i9 } & 33 \frac{1}{2} \\ \text { I } & 33 \\ 10 & 33 \\ 13 & 32 \\ 16 & 56\end{array}$

Treatment
o.r mg cobalt by mouth
daily
O. I mg cobalt intra-
venousiy daily
No cobalt

\begin{tabular}{|c|c|c|c|c|c|c|c|c|}
\hline \multicolumn{9}{|c|}{ Length of period (weeks) } \\
\hline I & 2 & 3 & 4 & 5 & 6 & 10 & 14 & 18 \\
\hline$-3 \frac{1}{2}$ & -5 & $-6 \frac{1}{2}$ & $-7 \frac{1}{2}$ & $-7 \frac{1}{2}$ & $-4 \frac{1}{2}$ & $+\mathbf{I}$ & +9 & $+18 \frac{1}{2}$ \\
\hline-8 & $*$ & - & - & - & - & - & - & - \\
\hline 一 & - & -4 & $-I \frac{1}{2}$ & $+x \frac{1}{2}$ & $+3 \frac{1}{2}$ & +15 & $+23 \frac{1}{2}$ & +25 \\
\hline$-I \frac{1}{2}$ & -4 & $-7 \frac{1}{2}$ & $*$ & - & - & - & - & - \\
\hline$-5 \frac{1}{2}$ & -9 & -13 & $-I I \frac{1}{2}$ & * & - & - & - & - \\
\hline$-3 \frac{1}{2}$ & -3 & $-7 \frac{1}{2}$ & $\bullet$ & - & - & - & $\ldots$ & $\ldots$ \\
\hline$-\mathrm{I} \frac{1}{2}$ & -4 & -10 & $*$ & - & - & - & - & - \\
\hline- & - & -6 & -4 & $-6 \frac{1}{2}$ & $-4 \frac{1}{2}$ & -3 & -9 & * \\
\hline
\end{tabular}

This experiment showed that the ration unsupplemented by cobalt was not adequate for normal nutrition. The lambs receiving cobalt by injection apparently derived no benefit from it and even lamb no. 875, which was in good condition and weighed $56 \mathrm{lb}$. when placed on the ration, also failed to gain weight and ultimately died, although initially its food consumption was satisfactory. One of the animals, no. 874 , receiving cobalt by mouth died soon after the experiment was begun. It was in very poor condition, weighing only $30 \mathrm{lb}$. at the beginning of the experiment, and failed to regain its appetite. Its companion, although it lost at first a considerable amount of weight, began to regain weight after 7 weeks and finally increased its initial weight by $24 \frac{1}{2} \mathrm{lb}$. in $2 \mathrm{I}$ weeks. From the beginning of the experiment this animal appeared brighter than the others, in spite of its loss in weight in the first few weeks.

The two replacement lambs, nos. 876 and 875 , provided an interesting comparison, for the better of the two, no. 876 , received no cobalt and died after 12 weeks, whereas no. 875 received cobalt by mouth and put on $34 \mathrm{lb}$. in 19 weeks. 


\section{Experiment 2}

The animals consisted of home-bred lambs and the experiment ran concurrently with the first. Owing to the severity of the deficiency set up in the animals in Exp. I, and to the excessive maize feeding, this group was used to ascertain whether a nicotinicacid deficiency was also induced by the large quantities of maize products in the ration.

The seven animals were maintained on the ration until they were no longer gaining weight. They were then subdivided into two groups, one of which received nicotinamide in saline by intramuscular injections daily, while the other (control) received saline only by intramuscular injection. The dose of nicotinamide was $10 \mathrm{mg} / \mathrm{kg}$ bodyweight.

The weight changes of these lambs are given in Table 5.

Table 5. Exp. 2. Weight changes (lb.) of home-bred Cheviot lambs at stated periods on cobalt-deficient ration

\begin{tabular}{|c|c|c|c|c|c|c|c|c|}
\hline \multirow[b]{3}{*}{ Lamb no. } & \multicolumn{2}{|c|}{ Weight } & & & & & & \\
\hline & \multirow{2}{*}{$\begin{array}{l}\text { When } \\
\text { put on } \\
\text { ration }\end{array}$} & \multirow{2}{*}{$\begin{array}{c}\text { When } \\
\text { injections } \\
\text { began }\end{array}$} & \multicolumn{6}{|c|}{ Week } \\
\hline & & & $\mathbf{r}$ & 2 & 3 & 4 & 5 & 6 \\
\hline $73 \circ$ & $40 \frac{1}{2}$ & $34 \frac{1}{2}(\mathrm{~N})$ & $-I$ & $-\frac{1}{2}$ & $-2 \frac{1}{2}$ & $-I \frac{1}{2}$ & $-3 \frac{1}{2} * \dagger$ & - \\
\hline 756 & $27 \frac{1}{2}$ & $24 \frac{1}{2}(N)$ & $-\frac{1}{2}$ & -1 & $-1 \frac{1}{2}+$ & - & - & - \\
\hline 757 & $39 \frac{1}{2}$ & $39 \frac{1}{2}(\mathrm{~N})$ & $+I$ & +1 & $+\mathrm{I} \frac{1}{2}$ & $+3 \frac{1}{2}$ & $+2 \frac{1}{2}$ & $+2 \frac{1}{2}$ \\
\hline $77 x$ & 46 & $42(N)$ & $-\frac{1}{2}$ & $-\frac{1}{2}$ & -2 & -4 & $-3 \dagger$ & - \\
\hline 768 & $33 \frac{1}{2}$ & 33 (S) & $+I \frac{1}{2}$ & +2 & +4 & +7 & $+7^{*}$ & +7 \\
\hline 772 & 30 & $29 \frac{1}{2}(S)$ & $+I$ & -2 & -2 & $-2 \frac{1}{2}$ & - & - \\
\hline 773 & $28 \frac{1}{2}$ & $25 \frac{1}{2}(\mathrm{~S})$ & 0 & $+2 \frac{1}{2} \dagger$ & - & - & - & - \\
\hline
\end{tabular}

(N): received nicotinamide intramuscularly.

(S): received saline intramuscularly.

- Received I mg cobalt daily by mouth after the $5^{\text {th }}$ week.

+ Died before next weekly weighing.

This experiment showed that injection of nicotinamide was of no benefit to the lambs; all of them, except nos. 757 and 768 , progressively became weaker and ultimately had to be killed when in a moribund condition. Injections were stopped when only four lambs were left and, instead, nos. $73^{\circ}$ and 768 received $\mathrm{I} \mathrm{mg} \mathrm{cobalt} \mathrm{in}$ solution daily by mouth, while nos. $77 \mathrm{I}$ and 757 were given a similar volume of saline orally. Nos. $73^{\circ}$ and 771 both became so weak within the next week that they had to be killed, but the two surviving animals, nos. 757 and 768 , were observed for the next Io weeks. The weight changes of these lambs while receiving cobalt or saline by mouth are given in Table 6.

These lambs consumed a more satisfactory quantity of food than the lambs of Exp. I, and there is no possibility of their subsequent decline being due solely to distaste for their food. All lambs ate sufficient quantities of food to demonstrate the fact that the diet was palatable and there was no doubt that, had they received cobalt orally, their subsequent performance would have been satisfactory. 
Table 6. Exp. 2. Weight changes (lb.) of two home-bred lambs, one of which received cobalt

$\begin{array}{ccccccccccccc}\text { Lamb } & \begin{array}{c}\text { Previous } \\ \text { no. }\end{array} & \begin{array}{c}\text { Weight when } \\ \text { treatment } \\ \text { changed }\end{array} & \overbrace{1} & 2 & 3 & 4 & 5 & 6 & 7 & 8 & 9 & 15 \\ 757 & (\mathrm{~N}) & 42(\mathrm{SM}) & -\frac{1}{2} & +1 \frac{1}{2} & +\frac{1}{2} & +\frac{1}{2} & 0 & -1 \frac{1}{2} & -3 & -2 \frac{1}{2} & -7 * & -7 \\ 768 & (\mathrm{~S}) & 40(\mathrm{C}) & 0 & +1 & +5 & +2 \frac{1}{2} & +9 & +7 \frac{1}{2} & +9 \frac{1}{2} & +14 \frac{1}{2} & +12 & +16 \frac{1}{2}\end{array}$

$(\mathrm{N})$ : received nicotinamide by intramuscular injection.

(SM): received saline by mouth.

- Lamb killed before the beginning of the gth week, when it was too weak to stand.

(S): received saline by intramuscular injection.

(C): received I $\mathrm{mg}$ cobalt daily by mouth.

\section{Experiment 3}

The animals in this experiment were used to study the effect of administration of cobalt into the duodenum:

two received the ration and saline into the duodenum daily;

two received the ration and $0.1 \mathrm{mg}$ cobalt into the duodenum daily;

one received the ration and $0.1 \mathrm{mg}$ cobalt by mouth daily.

The Blackface lambs proved to be sturdier than the Cheviot lambs in withstanding cobalt deficiency, as is indicated by the weight changes shown in Table 7 .

\section{Table 7. Exp. 3. Weight changes (lb.) of the Blackface lambs}

\begin{tabular}{|c|c|c|c|c|c|c|c|c|c|c|c|}
\hline \multirow[b]{2}{*}{$\begin{array}{l}\text { Lamb } \\
\text { no. } \\
90 \\
92\end{array}$} & \multirow[b]{2}{*}{$\begin{array}{c}\text { Treatment } \\
\text { Saline into duodenum }\end{array}$} & \multirow[b]{2}{*}{$\begin{array}{c}\text { Initial } \\
\text { wt. } \\
34 \frac{1}{2} \\
38 \frac{1}{2}\end{array}$} & \multicolumn{9}{|c|}{ Week } \\
\hline & & & $\begin{array}{c}2 \\
-9 \frac{1}{2} \\
-6 \frac{1}{2}\end{array}$ & $\begin{array}{r}4 \\
-13 \\
-5\end{array}$ & $\begin{array}{c}6 \\
-I I \\
-8 \frac{1}{2}\end{array}$ & $\begin{array}{l}8 \\
-5 \frac{1}{2} \\
-9\end{array}$ & $\begin{array}{l}10 \\
-4 \\
-7 \frac{1}{2}\end{array}$ & $\begin{array}{c}12 \\
-5 \frac{1}{2} \\
-10^{\circ}\end{array}$ & $\begin{array}{l}14 \\
-2 \frac{1}{2} \\
-\end{array}$ & $\begin{array}{l}16 \\
-2 \frac{1}{2} \\
-\end{array}$ & $\begin{array}{l}18 \\
-4 \frac{1}{2} \\
-\end{array}$ \\
\hline $\begin{array}{l}93 \\
94\end{array}$ & Cobalt into duodenum & $\begin{array}{l}41 \\
34 \frac{1}{2}\end{array}$ & $\begin{array}{c}-8 \frac{1}{2} \\
0\end{array}$ & $\begin{array}{l}-8 \\
+1 \frac{1}{2}\end{array}$ & $\begin{array}{l}-8 \\
+7\end{array}$ & $\begin{array}{l}-\mathrm{rr} \frac{1}{2} \\
+6 \frac{1}{2}\end{array}$ & $\begin{array}{l}-13^{*} \\
+7 \frac{1}{2}\end{array}$ & $\overline{+6}$ & $\overline{+6 \frac{1}{2}}$ & $\overline{+3}$ & $\overline{+5}$ \\
\hline 91 & Cobalt by mouth & $35 \frac{1}{2}$ & $-\frac{1}{2}$ & +1 & +5 & $+6 \frac{1}{8}$ & $+12 \frac{1}{2}$ & $+13 \frac{1}{2}$ & $+19 \frac{1}{2}$ & $+22 \frac{1}{2}$ & +26 \\
\hline
\end{tabular}

The shortest survival of any lamb in this group was I I weeks, in contrast to the Cheviot lambs in Exps. I and 2, the majority of which died in 6 weeks. The longest survival in the Blackface group without cobalt was 18 weeks and this lamb was then still far from moribund, although stunted and very thin.

The peculiar part of this experiment was the behaviour of two lambs receiving cobalt into the duodenum; one behaved as though it received no cobalt at all, whereas the other appeared to derive some benefit, although it made no constant progress. The only lamb that throve was the one that received $0.1 \mathrm{mg}$ cobalt daily by mouth: it gained $26 \mathrm{lb}$. in 18 weeks. An attempt was made to resuscitate lamb no. 92 by giving it $\mathrm{I} \mathrm{mg}$ cobalt by mouth daily after the 7 th week, when there was no doubt as to its deficiency; this treatment was continued for the next 3 weeks; in spite of this the animal made no improvement and ultimately died.

A study of the figures for food consumption given in Table 8 shows that the appetite was closely related to the history of the lamb, and the depressed food con- 
sumption of lamb no. 94 is a clear indication that the cobalt it received by duodenum did not have the same result as the same quantity of cobalt given by mouth to lamb no. 9 I.

\section{Table 8. Exp. 3. Food consumption (g) of Blackface lambs}

\begin{tabular}{|c|c|c|c|c|c|c|c|c|c|c|}
\hline \multirow[b]{3}{*}{ Week } & \multicolumn{4}{|c|}{ Saline in duodenum } & \multicolumn{4}{|c|}{ Cobalt in duodenum } & \multirow{2}{*}{\multicolumn{2}{|c|}{$\overbrace{\text { Lamb no. } 9 \mathrm{I}}^{\text {Cobalt by mouth }}$}} \\
\hline & \multicolumn{2}{|c|}{ Lamb no. 90} & \multicolumn{2}{|c|}{ Lamb no. 92} & \multicolumn{2}{|c|}{ Lamb no. 93} & \multicolumn{2}{|c|}{ Lamb no. 94} & & \\
\hline & Hay & $\begin{array}{l}\text { Maize } \\
\text { mixture }\end{array}$ & Hay & $\begin{array}{l}\text { Maize } \\
\text { mixture }\end{array}$ & Hay & $\begin{array}{c}\text { Maize } \\
\text { mixture }\end{array}$ & Hay & $\begin{array}{l}\text { Maize } \\
\text { mixture }\end{array}$ & Hay & $\begin{array}{c}\text { Maize } \\
\text { mixture }\end{array}$ \\
\hline I & 100 & 340 & 50 & 345 & I IO & 300 & 210 & 425 & 380 & 565 \\
\hline 2 & 0 & 170 & 0 & 1090 & 90 & 780 & $45^{\circ}$ & 920 & 540 & 1440 \\
\hline 3 & 30 & 100 & 50 & 1085 & 120 & 800 & 790 & I I20 & 330 & 1495 \\
\hline 4 & o & I64 & 260 & 694 & 60 & 744 & $75^{\circ}$ & II 84 & 680 & 1624 \\
\hline 5 & o & 374 & 350 & 654 & 90 & 894 & 1140 & 1614 & 760 & 1844 \\
\hline 6 & 200 & 654 & 600 & 744 & 460 & 584 & 1260 & 1864 & 850 & 2974 \\
\hline 7 & $65^{\circ}$ & 794 & 720 & 824 & 870 & 624 & 1340 & 2214 & 1030 & 3154 \\
\hline 8 & 570 & 2094 & $55^{\circ}$ & 564 & 1040 & 794 & 1400 & 2104 & 600 & 2814 \\
\hline 9 & 760 & 1684 & 610 & 1024 & 780 & 774 & 1300 & 1714 & 670 & 3734 \\
\hline 10 & 960 & 1234 & 240 & IOI $4_{4}$ & 340 & 524 & 1050 & 1854 & $5^{80}$ & 3684 \\
\hline 11 & 960 & 2014 & 480 & 1374 & 260 & 200 & 1050 & 2084 & 620 & 4204 \\
\hline 12 & 1050 & 1254 & $3^{80}$ & 1424 & - & - & 960 & 1734 & 440 & 4604 \\
\hline 13 & 1050 & 1894 & 100 & I 404 & 一 & - & 880 & 1322 & 230 & 5414 \\
\hline 14 & 1050 & 1644 & IIO & I I 82 & - & - & 1050 & 2014 & 400 & 5364 \\
\hline 15 & 1050 & 1254 & - & - & - & - & 900 & 2044 & $25^{\circ}$ & 5504 \\
\hline$\times 6$ & $105^{\circ}$ & I 324 & - & - & - & - & ráo & I 784 & 410 & 4244 \\
\hline 17 & 1050 & 1004 & - & - & - & - & 1000 & 1964 & 410 & 4664 \\
\hline I 8 & 1050 & 1034 & - & - & - & - & $8_{50}$ & I 864 & 570 & 4374 \\
\hline
\end{tabular}

\section{Concentration of cobalt in the liver}

Values for the livers of most of the lambs of Exps. I-3 are given in Table 9.

There was very little cobalt in the livers of lambs given no cobalt, and the figures found are lower than any other previously recorded from cobalt-deficient animals in the field. Oral dosing with $0.1 \mathrm{mg}$ cobalt daily for 18 weeks or more led to substantial deposits of cobalt in the liver. Cobalt by mouth for a period of $\mathrm{I}$ or 2 weeks in animals in the last stages of deficiency led to little or no deposition of cobalt in the liver. At the rate of I mg daily, cobalt did not produce a large deposition in the livers, except in one animal (no. 92) which died 3 weeks after the treatment was begun.

Intravenous injection of cobalt and the introduction of cobalt into the duodenum both increased liver cobalt considerably, the former to a greater extent than the latter.

\section{Experiment 4}

The lambs in this experiment, approximately 8 months old at the beginning, were older than those in the previous experiments. They were placed on the deficient ration as soon as they arrived and none of them received any cobalt. All animals were operated upon ro-I4 days later for the insertion of either an abomasal or a duodenal cannula. Rumen cannulas were placed in eight of them 2 weeks later. During this preliminary period, while the animals were becoming accustomed to the ration, some lost weight and some increased in weight; the greatest loss was $3 \mathrm{lb}$. and the greatest gain $2 \mathrm{lb}$. During the next Io days $0.1 \mathrm{mg}$ cobalt was given daily either into the abomasum or duodenum by syringe through the cannula or else by mouth. Con- 
Table 9. Concentration of cobalt in the liver of lambs in Exps. I-3

Lamb
87
87
87
9
75
75
773
77
77
87
874
9
768
730
92
869
871
93
94

\begin{tabular}{|c|c|c|}
\hline & & \\
\hline Treatment & $\begin{array}{c}\text { Concentration } \\
\text { in liver ash } \\
\text { (p.p.m.) }\end{array}$ & $\begin{array}{l}\text { Total in liver } \\
(\mu \mathrm{g})\end{array}$ \\
\hline No cobalt & $\begin{array}{l}<0.6 \\
<0.3\end{array}$ & $\begin{array}{l}<x \cdot 5 \\
<x \cdot 0\end{array}$ \\
\hline & $<0.5$ & $<2 \cdot 5$ \\
\hline & $<0.5$ & $<\mathrm{I} \cdot 0$ \\
\hline & $<0.2$ & $<0.6$ \\
\hline & $\begin{array}{l}<0.3 \\
<0.2\end{array}$ & $\begin{array}{l}<\mathrm{I} .5 \\
<0.8\end{array}$ \\
\hline & $\begin{array}{l}0.39^{*} \\
0.71^{*}\end{array}$ & $\begin{array}{l}1 \cdot 5^{*} \\
2.0^{*}\end{array}$ \\
\hline o. I mg cobalt by mouth daily & $14 \%$ & 79 \\
\hline - I mg cobalt by mouth daily (lived io days) & 0.3 & I \\
\hline 0. I mg cobalt by mouth daily & $15 \cdot 0$ & 86 \\
\hline I mg cobalt by mouth daily & $x^{2} 5$ & $9 \cdot 7$ \\
\hline I $\mathrm{mg}$ cobalt by mouth daily for to days & $3 \cdot 0$ & 12 \\
\hline I $\mathrm{mg}$ cobalt by mouth daily (for 3 weeks only) & 22 & 80 \\
\hline 0.1 mg cobalt daily intravenously & 18 & 67 \\
\hline o. I mg cobalt daily intravenously & 39 & 89 \\
\hline - I mg cobalt daily into duodenum & 6 & 22 \\
\hline 0.1 mg cobalt daily into duodenum & 7 & 30 \\
\hline
\end{tabular}

* Additional chemical concentration allowed the exact values in the last two livers to be obtained.

siderable difficulty was experienced in dosing into the abomasum, as spillage was liable to occur; the method was accordingly changed to that described earlier in this paper (p. 180).

The initial weights and the arrangement of the experiment are given in Table ro.

Table 10. Exp. 4. Weight changes (lb.) of Border Leicester-Blackface lambs

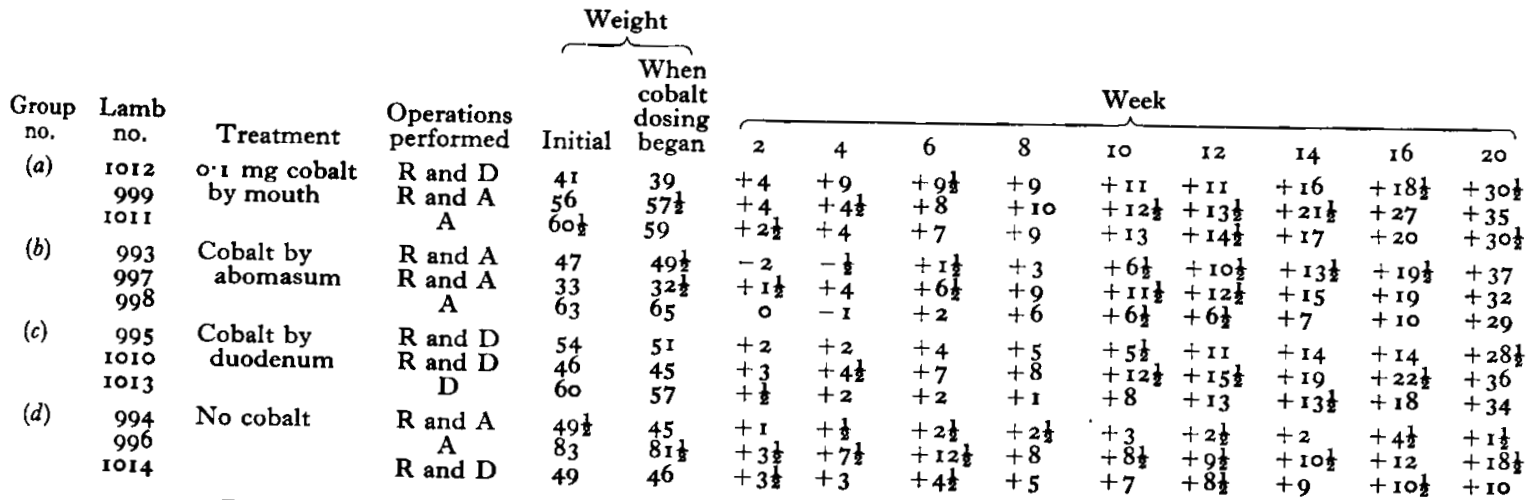

$R$ : rumen cannula inserted. A: abomasal cannula inserted. D : duodenal cannula inserted.

The heaviest animal, no. 996 , was placed in the group to receive no cobalt; this animal and no. 994 both ultimately died 8 months later and were the only casualties in this experiment. Animal no. ror 4 received $5 \mu \mathrm{g}$ cobalt by mouth daily during the last few months when it was maintained on the ration, and it survived the experiment. 
The weight gains made by all animals receiving cobalt, whether by mouth, abomasum or duodenum, were all significantly greater than those made by the sheep receiving no cobalt. An apparent difference, however, was found between the oral, abomasal and duodenal groups during the first ro weeks of the experiment and this has been analysed in detail. After 20 weeks, however, all three groups were level, and from this point onwards all behaved as though they were receiving cobalt by mouth. The detailed weight changes during the first 20 weeks are given for each individual sheep in Table ro.

When the fortnightly weight changes after ro weeks are compared it is seen that those lambs receiving cobalt by mouth had gained $\mathrm{I} I-13 \mathrm{lb}$., those receiving cobalt by abomasum, $6 \frac{1}{2}-1 \mathrm{I} \frac{1}{2} \mathrm{lb}$., those receiving cobalt by duodenum, $5 \frac{1}{2}-12 \frac{1}{2} \mathrm{lb}$., and those receiving no cobalt, $3^{-8 \frac{1}{2}} \mathrm{lb}$.

In each of the last three groups (see Table Io), one sheep made a weight gain comparable to those of group (a) receiving cobalt by mouth. Thus no. 996 , after 6 weeks, had put on more weight than any other sheep, although receiving no cobalt. Later she lost weight and months later died. Lambs nos. 997 and roro similarly made weight gains equal to those of the lambs receiving cobalt by mouth. What is interesting, however, is that all other lambs, outside group $a$, nos. 993, 998, 995, 1013, 994 and I014, made very poor weight increases, and that 1o weeks after receiving regular cobalt treatment or no treatment they had made much less progress than the lambs in group $(a)$. This suggests that the cobalt introduced into the duodenum or abomasum did not have the same effect in these organs as cobalt given by mouth. But this suggestion must be treated with caution, for statistical analysis of the weight changes shows that the differences between the groups were not significant until the I2th week, when only group $(d)$ receiving no cobalt differed from the others.

The concentrations of cobalt found in the rumen contents are given in Table II.

$\begin{array}{cccc}\text { Table I I. Exp. 4. Concentration of cobalt in rumen-liquor ash of lambs } \\ \text { Group no. } & \text { Lamb no. } & \text { Treatment } & \text { Cobalt in p.p.m. } \\ \text { (a) } & 1012 & \text { Cobalt by mouth } & 3.1 \\ & 999 & & 4 \cdot 4 \\ \text { (b) } & 993 & \text { Cobalt by abomasum } & 2 \cdot 7 \\ & 997 & & 1.6 \\ \text { (c) } & 995 & \text { Cobalt by duodenum } & 2 \cdot 2 \\ & 1010 & & 5.2 \\ \text { (d) } & 994 & \text { No cobalt } & 0.4 \\ & 1014 & & 0.5\end{array}$

These figures show conclusively that, although cobalt was made available in the abomasum and duodenum, it attained a concentration in the rumen three or more times greater than in the rumen of the lambs receiving no supplementary cobalt. With the exception of lamb no. Ioro, however, the concentration in the rumen was lower in the lambs of groups $(b)$ and $(c)$ than in those of group $(a)$, which received cobalt by mouth.

Utilization of food by the lambs of Exp. 4. In order to ascertain whether the utilization of food was different in lambs in the different groups, the starch equivalent required for $\mathrm{I} \mathrm{lb}$. live-weight increase over and above that needed for maintenance 
was calculated for each lamb during four 5-week periods. The weight of each lamb for each period was taken as the mid-point between the weights at the beginning and end of each period. The maintenance requirements in starch equivalents for each sheep at this weight and the starch equivalents consumed were calculated from the tables given by Halnan \& Garner (1944). The hay was assumed to be poor meadow hay with a starch equivalent of 22. The results of these analyses are given in Table 12.

Table 12. Exp. 4. Utilization of food by lambs. Starch equivalents (lb.) consumed in excess of maintenance requirements per lb. live-weight increase

\begin{tabular}{|c|c|c|c|c|c|}
\hline Lamb no. & $\begin{array}{l}\text { Period I, } \\
\text { Ist-5th week }\end{array}$ & $\begin{array}{c}\text { Period 2, } \\
\text { 6th-Ioth week }\end{array}$ & $\begin{array}{c}\text { Period 3, } \\
\text { I Ith-I 5th week }\end{array}$ & $\begin{array}{c}\text { Period 4, } \\
\text { 16th-2oth week }\end{array}$ & $\begin{array}{l}\text { All periods, } \\
\text { Ist-2oth week }\end{array}$ \\
\hline $\begin{array}{r}994 \\
996 \\
1014\end{array}$ & $\begin{array}{l}1.0 \\
2.5 \\
0.8\end{array}$ & $\begin{array}{l}-* \\
4.7 \\
2.6\end{array}$ & $\begin{array}{r}16.3 \\
3.7 \\
2 \cdot 7\end{array}$ & $\begin{array}{l}-* \\
r \cdot 2\end{array}$ & $\begin{array}{r}20 \cdot 5 \\
2 \cdot 6 \\
2 \cdot 7\end{array}$ \\
\hline $\begin{array}{r}995 \\
1010\end{array}$ & $\begin{array}{l}2 \cdot 6 \\
2 \cdot 3\end{array}$ & $\begin{array}{l}3 \cdot 7 \\
2 \cdot 4\end{array}$ & $\begin{array}{l}1 \cdot 9 \\
2 \cdot 8\end{array}$ & $\begin{array}{l}1 \cdot 9 \\
I \cdot 9\end{array}$ & $\begin{array}{l}2 \cdot 2 \\
2 \cdot 3\end{array}$ \\
\hline 1013 & $2 \cdot 3$ & $3 \cdot I$ & $2 \cdot 6$ & $\begin{array}{l}29 \\
x \cdot 7\end{array}$ & $2 \cdot 2$ \\
\hline $\begin{array}{l}993 \\
997 \\
998\end{array}$ & I.5. & $\begin{array}{l}2 \cdot 4 \\
2 \cdot 7 \\
1 \cdot 6\end{array}$ & $\begin{array}{r}3.6 \\
2.5 \\
13.9\end{array}$ & $\begin{array}{l}I \cdot 8 \\
x \cdot 6 \\
I \cdot 3\end{array}$ & $\begin{array}{l}2 \cdot 6 \\
2 \cdot 0 \\
1 \cdot 9\end{array}$ \\
\hline $\begin{array}{r}999 \\
101 x \\
1012\end{array}$ & $\begin{array}{l}2 \cdot 4 \\
2 \cdot 2 \\
1 \cdot 8\end{array}$ & $\begin{array}{l}2 \cdot 8 \\
3 \cdot 4 \\
2 \cdot 4\end{array}$ & $\begin{array}{l}2 \cdot 4 \\
1 \cdot 8 \\
5 \cdot 2\end{array}$ & $\begin{array}{l}3 \cdot 3 \\
2 \cdot 1 \\
2 \cdot 6\end{array}$ & $\begin{array}{l}2 \cdot 8 \\
2 \cdot 6 \\
2 \cdot 8\end{array}$ \\
\hline
\end{tabular}

The results over the full 20-week period are regular for all animals except no. 994, which gained little weight in the 20-week period. In five periods certain lambs made no gains yet they ate enough food to do so. Three of these periods occurred with the cobalt-deficient lambs, nos. 994 and ror4, and the other two in the group receiving cobalt by abomasum during the first 5 -week period. In one of these animals, no. 998 , a second period was found in which the starch equivalents required for $\mathrm{I} l \mathrm{lb}$. increase in weight were very high, $13 \cdot 9$.

These calculations, however, show that there was no constant difference in food utilization between the four groups of animals, and the weight increases were closely allied to food consumption.

\section{DISCUSSION}

The unusual nature of the ration used in these experiments was a disadvantage, for lambs coming from pasture did not eat it readily. This was most obvious with the lambs in Exp. I. Nevertheless, when cobalt was given by mouth, most lambs made weight gains of $\mathrm{I}-2 \mathrm{lb}$./week; although these are not optimal gains, they at least show that this ration allows growth to occur in spite of the small quantity of hay fed. One disquieting feature is that lambs in an advanced state of deficiency could not be revived when given cobalt by mouth. It is possible that this was due to changes in the bacterial flora of the rumen, and that when cobalt was again given by mouth bacteria that would otherwise take up cobalt, as found by Tosic \& Mitchell (1948), had lost their ability to do so or were so reduced in numbers that the total effect was unappreciable. This hypothesis presupposes that cobalt is of use to the sheep only indirectly and that it is primarily essential for the metabolism of unknown species of rumen bacteria. In support there is the fact that the liver of one lamb (no. 92), which 
failed to revive after the administration of I $\mathrm{mg}$ cobalt by mouth daily for 3 weeks, contained $80 \mu \mathrm{g}$ cobalt in contrast to that of a further lamb (no. 768 ), which received the same dose for a longer period and made weight gains, whose liver contained 9.7 $\mu \mathrm{g}$, suggesting that in lamb no. 92 more cobalt was available for absorption.

The severity of the deficiency produced can be assessed by comparing the figures for total cobalt in the liver, given in Table 9, with those given by McNaught (1948-9) for naturally occurring cases of cobalt deficiency-'bush sickness'-in New Zealand. McNaught ( $1948-9$ ) found the total cobalt content of the livers of lambs $5-9$ months old suffering from 'bush sickness' to be $\mathrm{I}-8 \mu \mathrm{g}$, compared with Io-50 $\mu \mathrm{g}$ for healthy lambs, whereas the livers of lambs $12-20$ months old suffering from 'bush sickness' contained 2-7 $\mu \mathrm{g}$. It seems probable from these figures that the cobalt available in the ration fed to our lambs was less than is present in deficient New Zealand pastures. McNaught gives the average yearly content of the dry matter of pasture grass in two deficient areas as 0.06 p.p.m., so that the average daily intake would be $60 \mu \mathrm{g}$, assuming that the animals eat I $\mathrm{kg}$ dry matter daily. It seems possible that the cobalt of grass is more readily available than the cobalt of hay: most of the cobalt in our ration was contained in the hay. Therefore, under our conditions, the maximum intake of cobalt, $55 \mu \mathrm{g}$ daily, may have induced a far more severe degree of deficiency than would be encountered out of doors; the severity and rapid onset of the deficiency produced by feeding the ration, compared with the history of naturally occurring pining in Scotland, supports this hypothesis.

The fact that the two lambs of Exp. 3, which received cobalt daily into the duodenum, remained in a deficient state, even though one managed to maintain its weight over a considerable period, is convincing evidence that cobalt is not required in the intestines.

The fact that the lambs in Exp. 4 responded to the introduction of cobalt into the duodenum does not invalidate this conclusion, for it was found that the cobalt found its way into the rumens of these animals. As intravenous injections of considerable amounts of cobalt have some benefit (Ray et al. 1948), it is possible that cobalt can enter the rumen in the saliva or through the rumen wall. It is also possible that, in spite of the fact that the floor was slatted, the lambs may have obtained some cobalt from the faeces.

The same arguments apply to the groups with abomasal fistulas, but here oral diffusion into the rumen can be added to the possible reasons for the presence of cobalt in the rumen. The question whether free cobalt is necessary in the abomasum or the first part of the duodenum still remains to be settled. The retarded growth rate of two of the three lambs receiving cobalt by abomasum during the first ro weeks of the experiment, however, suggests, but does not prove, that the presence of cobalt is necessary only in the rumen, reticulum and omasum. It has been long recognized that cobalt deficiency is accompanied by lack of appetite, but no careful measurements of food consumption have been made. Recently, Stewart (195I) showed that the weight changes of cobalt-deficient sheep were closely related to the appetite, and our results confirm this. In addition, they suggest that differences in the utilization of the food cannot be offered as an explanation of the deficiency syndrome, for only 
in one animal in which deficiency was severe was poor utilization detected on the basis of theoretical values.

As intravenous injection of cobalt does not cure cobalt deficiency, the estimation of the adequacy of the cobalt available to the animal is better judged by the concentrations in the rumen contents than by the amount present in the liver. Injection of cobalt and its introduction into the duodenum gave a substantial increase in the total cobalt in the liver of our lambs and yet these animals continued to pine. Liver cobalt is not therefore a physiological measure of cobalt adequacy and since rumen contents are easily obtained and ashed in comparison with liver samples, examination of rumen contents as a measure of the cobalt 'status' of the animal has much to recommend it.

\section{SUMMARY}

I. Cobalt deficiency in lambs has been maintained or produced by feeding a cobaltlow ration.

2. Administration of cobalt intravenously or into the duodenum at the rate of $0.1 \mathrm{mg}$ daily did not cure the deficient lamb.

3. Administration of cobalt into the duodenum or abomasum in quantities greater than $0.1 \mathrm{mg}$ allowed growth to occur at a rate similar to that of lambs receiving $0.1 \mathrm{mg}$ cobalt daily by mouth.

4. A higher concentration of cobalt was found in the rumen of lambs receiving cobalt into the abomasum or duodenum than in those receiving no cobalt.

5. The concentration of cobalt in the liver was substantially increased by the administration of cobalt intravenously, into the duodenum or by mouth, but there was no correlation between liver cobalt and signs of deficiency.

6. The weight changes of cobalt-deficient lambs were closely related to the quantity of food consumed.

Since this paper was sent to press a report from America (Smith \& Koch, I95 I) has appeared to the effect that very large doses of vitamin $B_{12}$ given by injection allow practically normal growth rates in cobalt-deficient lambs. Vitamin $B_{12 b}$ seems to be as effective as vitamin $B_{12}$ itself.

\section{REFERENCES}

Askew, H. O. \& Dixon, J. K. (1936). N.Z. F. Sci. Tech. r8, 73.

Comar, C. L. \& Davis, G. K. (1947). Arch. Biochem. 12, 257.

Comar, C. L., Davis, G. K., Taylor, R. F., Huffman, C. F. \& Ely, R. E. (1946). F. Nutrit. 32,6 r.

Halnan, E. T. \& Garner, F. H. (1944). The Principles and Practice of Feeding Farm Animals, 2 nd ed. London: Longmans, Green and Co.

Keener, H. A., Percival, G. P., Ellis, G. H. \& Beeson, K. C. (1950). F. Anim. Sci., 9, 404.

Lines, E. W. (1935). F. Coun. sci. industr. Res. Aust. 8, 117.

McNaught, K. J. (1948-9). N.Z. F. Sci. Tech. 30, sect. A, 26.

Marston, H. R. (1935). Ұ. Coun. sci. industr. Res. Aust. 8, I I I.

Marston, H. R. \& Lee, H. J. (1949). Nature, Lond., x64, 529.

Masson, M. (1950). Brit. $\mathcal{F}$. Nutrit. 4, viii.

Mitchell, R. L. (1948). Tech. Commun. Bur. Soil Sci. Harpenden, no. 44.

Mitchell, R. L. \& Scott, R. O. (1948). Spectrochim. Acta, 3, 367.

Ray, S. N., Weir, W. C., Pope, A. L., Bohstedt, G. \& Phillips, P. H. (1948). F. Anim. Sci. 7, 3.

Smith, S. E. \& Koch, B. A. (1951). F. Anim. Sci. 10, 1062.

Stewart, J. (1947). Biochem. F. 41, xlii.

Stewart, J. (195I). Brit. F. Nutrit. 5, i.

Tosic, J. \& Mitchell, R. L. (1948). Nature, Lond., I62, 502.

Underwood, E. J. \& Filmer, J. F. (1935). Aust. vet. F. 11, 84. 